\title{
Nonclassical and postnonclassical epistemology in Lev Vygotsky's cultural-historical approach to clinical psychology
}

\author{
Yury P. Zinchenko, Elena I. Pervichko \\ Lomonosov Moscow State University, Moscow, Russia
}

This article presents a historiographic and theoretical methodological study of the establishment of the fundamental theses of L. S. Vygotsky's cultural-historical concept within the field of clinical psychology.

We prove the potency of contemporary philosophical concepts that help distinguish the types of scientific rationality (classical, nonclassical, and postnonclassical) when these concepts are applied to reflection about the development of psychology and the paradigmatic cultural-historical concept suggested by Vygotsky and the L. S. Vygotsky-A. R. Luria syndrome approach.

Present studies of the works of Vygotsky and his followers demonstrate that the fundamentals of the cultural-historical concept reveal not only the nonclassical but also the postnonclassical model of scientific rationality. They are characterized by the postnonclassical understanding of the object and method of psychological study and the postnonclassical mode of thinking of contemporary psychologists.

The general methodological requirements formulated for the organization of mental studies, on the whole, are in line with the requirements introduced for the study of complex self-developing systems. Vygotsky produced arguments to prove that the Vygotsky-Luria syndrome approach describes mental syndromes as dynamic structures in that they display the features of self-organization, self-determination, and adaptive rationality. Hence, they can be regarded as open self-developing systems.

We propose and verify the hypothesis that syndrome analysis, because of the features of postnonclassical modeling of scientific rationality that it reveals, may be regarded as a theoretically productive methodological approach in contemporary psychological studies.

Keywords: nonclassical epistemology, postnonclassical epistemology, self-developing systems, cultural-historical psychology, Vygotsky-Luria school, psychological syndrome analysis, higher mental functions

This article is an endeavor in historiographic reflection about the formation of the methodological principles of clinical psychology in the works of L. S. Vygotsky within the context of the analysis of scientific rationality. 
The purpose of our work is to demonstrate that the fundamentals of the cultural-historical concept suggested by Vygotsky and further developed in the methodology of the Vygotsky-Luria syndrome approach reveal the origins of not only the nonclassical but also the postnonclassical model of scientific rationality.

We presume that this line of analysis of Vygotsky's cultural-historical concept will provide an increased understanding of the true significance of this concept for the development of clinical psychology.

Consideration of these issues is urgent for the contemporary development of psychological science. The present state of affairs (in psychological science in general and in clinical psychology in particular) provides an illustrative example of the increasingly differentiated structure of scientific knowledge. This state is characterized by marked "methodological liberalism and pluralism," which shapes various theoretical and applied branches of the science. Under certain conditions the increase in methodological pluralism may be regarded as a sign of crisis (Vygotsky, 1997b; Sokolova, 2011). Hence, the issues of methodology come to the foreground of scientific endeavors.

For clinical psychology, methodological matters appear as even more pressing and acute. Clinical psychology emerged as a separate discipline at the juncture of psychology and medicine at the beginning of the 20th century; therefore, it immediately faced the urgency of reflecting about the entire "legacy" of methodological issues in both "paternal" sciences. In the contemporary social situation, which is distinguished by striking cultural shifts and social uncertainty, clinical psychology "feels a need for new methodological approaches that would provide for the development of new technologies of diagnostics and social-psychological rehabilitation" (Sokolova, 2012, p. 42).

Following the normative methodological requirements set by Vygotsky, Russian psychology has traditionally given close consideration to the methodological foundation of its studies (Kornilova \& Smirnov, 2011; Vygotsky, 1997b; Zinchenko, 2006; Zinchenko, 2011; Zinchenko \& Smirnov, 1983; and others).

Nevertheless, in the 1980s and 1990s a wave of criticism of Soviet psychology arose; it became a kind of fashion to ignore Marxist methodology. In addition, boundless opportunities appeared to access foreign sources that would enlighten new methodological principles mostly unknown to Russian specialists. These two developments resulted in a considerable expansion of most empirical studies in Russian psychology. As is well known, such studies dwell exclusively on the search for correlations between objects and phenomena. Hence they fail to contribute to a particular science or to a general scientific worldview.

Thus, contemporary clinical psychology as a scientific field of study is faced with urgent methodological issues.

In recent times Russian psychology has witnessed repeated attempts at theoretical methodological and historiographic analyses of psychological accomplishments. They are conducted on the basis of the widely known classification of the types of scientific rationality suggested by V. S. Styopin. This classification provides grounds for designating the following types (and stages) in the development of scientific knowledge: classical, nonclassical, and postnonclassical (Guseltseva, 2009; Klochko, 2007, 2008; Kornilova \& Smirnov, 2011; Sokolova, 2011; Styopin, 2003; 
Zinchenko, 2006; Zinchenko, 2011; Zinchenko \& Pervichko, 2012a; Zinchenko \& Pervichko, 2012c; and others)

In his philosophical methodological works Styopin proves that the transition from classical to nonclassical science and, further, to its postnonclassical stage brought profound changes in the scientific worldview, in the ideals and norms of science, as well as in its philosophical foundations. He suggests the following criteria for the types of rationality: (1) distinctive features of a systemic organization of investigated objects and different types of worldview; (2) certain distinctions of means and operations of activity as represented in the ideals and norms of science; (3) peculiar values and purposes of the subject and their assessment as expressed in the specifics of the philosophical foundations of the scientific worldview (Styopin, 2003, 2011).

To study objects represented in elementary systems, the means of classical science will suffice; nonclassical science operates with self-regulating systems, and postnonclassical science copes with complex self-developing systems. The transition from classical to nonclassical and, still further, to postnonclassical science changes the type of reflection about the activity:

[Reflection moves] from elimination of everything which does not belong to the object (classical approach) to consideration of the correlation between the object's characteristics in question and the peculiarities of the means and operations (nonclassical) and, further, to the comprehension of the values and purposes of the subject of scientific endeavors in correlation with social values and purposes. (Styopin, 2003, p. 14)

These philosophical methodological theses frequently enter psychological discourse in Russia when it concerns the issues of intrapsychological reflection about the development of scientific knowledge and the designation of the paradigmatic status of contemporary psychology.

Let us trace the formation of psychological science within the analysis of the types of scientific rationality. The main purpose is to demonstrate the fact that the basic provisions of the cultural-historical concept suggested by Vygotsky and the Vygotsky-Luria syndrome represented the origins of postnonclassical rationality because of those provisions' postnonclassical understanding of the object and method of study. This fact testifies to Vygotsky and Luria's postnonclassical way of thinking, which, we assume, makes the cultural-historical approach applicable to theoretical and practical issues in contemporary clinical psychology.

Formulation of the basic theses of classical rationality is traditionally attributed to philosophical rationalism and dualism, which are primarily represented in the works of René Descartes; as early as the 17th century, Descartes introduced the dichotomy of a studied subject and an object of that study, as indicated by the opposition of matter and spirit, mind and body. The classical stage of science development postulated and accentuated the existence of two universes: internal/psychic and external/nonpsychic.

Classical systems appeared in psychology at the end of the 19th century; they were actively developed up to the 1950s and 1960s. Classical rationality in psychology is represented by a rather vast diversity in concepts and approaches, most of which are heavily influenced by the natural sciences. Classical science studies objects shaped into elementary systems. Classical psychology also appears as an 
analytical discipline: it tends to boil down complex phenomena to simple ones and designates "mental" as "external." Ideals of classical science inspired the psychology of consciousness, suggested by Wilhelm Wundt; the theory of higher nervous activity, introduced by I. P. Pavlov; I. M. Sechenov's reflex theory; the psychology of memory, developed by H. Ebbinghaus; and Edward Titchener's structuralism. They are to be found also in V. M. Bechterev's reflexology and the psychophysiological works of A. F. Lazursky, among others. Clinical psychology as a separate branch of science came into being within the framework of classical epistemology.

Gradually, as science encountered more and more complicated objects for study, the inadequacy of the categorical scale suggested for elementary systems became clearly apparent.

Nonclassical science focused on complex systems. One of the distinguishing features of such a system is the presence of systemic qualities of the whole, which cannot be reduced to the qualities of its constituent elements. Establishment of the nonclassical type of rationality in psychology was closely connected with its development as a humanitarian science, with recognition of humans and their psyches as an object of study unrivaled in its specificity. According to Leont'ev (2005), psychology was transformed into a nonclassical science mostly through the discoveries made in the 1920s and 1930s by K. Levin, Vygotsky, M. M. Bahtin, A. Adler and Ludwig Binswanger.

Vygotsky, for certain, occupies a special place in the list. His work "The Historical Meaning of the Crisis in Psychology" (1997b) suggests theoretical reflection about the fundamentals of "empirical" (classical) psychology. Vygotsky gives a pithy description of the crisis of empirical psychology, suggesting plausible ways out of that state. He was among the first to present a psychological theory (a concept of mental development) that was based not on empirical data but on certain theoretical assumptions about the social character of consciousness and the higher mental functions and about symbols as mediators of the higher mental functions.

We can formulate the general genetic law of cultural development as follows: every function in the cultural development of the child appears on the stage twice, in two planes, first, the social, then the psychological, first between people as an intermental category, then within the child as a intramental category.... We are justified in considering the thesis presented as a law, but it is understood that the transition from outside inward transforms the process itself, changes its structure and functions. (1997b, p. 106)

Thus, Vygotsky formulated a generalized law of development of mental functions: in the course of socialization, through the mechanism of exteriorization, intersubjective functions are transformed into intrasubjective ones.

This example, we suggest, provides conclusive proof of fundamental differences in basic ideas of the cultural-historical concept introduced by Vygotsky and of the postulates of Cartesian (classical) psychology.

Thus, the idea of higher mental functions within the cultural-historical concept developed by Vygotsky sets a clear example of negotiating the "postulate of immediacy" by looking for "a meditative link" and overcoming the opposition of "internal" and "external"; these were to become features of nonclassical rationality to distinguish it from classical rationality. 
We traditionally refer to the most widely known theoretical concepts of the second part of the 20th century as examples of the nonclassical type of rationality.

Historians and methodologists of psychological science agree that nonclassical psychology in Russia reached its pinnacle in the 1960s to the 1980s. However, the 1990s demanded considerably intensified methodological reflection to define the methodological status of psychology in a dramatically changing world.

The very essence of the contemporary paradigmatic shift in science lies in the fact that scientists have come to observe new objects for study-complex, open self-developing systems. The modern state of scientific knowledge and technologies and further perspectives on their development in the near future can be described by the notion of postnonclassical science (Budanov, 2009; Kurdyumov, 2000; Lektorsky, 2006; Prigogine, 1989; Styopin, 2003, 2011; and others). The notion of postnonclassical science suggested by Styopin is regarded as well established in present scientific discourse (Styopin, 2003).

In the most general definition, a self-developing system may be described as a system that in itself contains the prospect for further development; it independently chooses the aims of its further development and the inner criteria for their achievement. This definition presumes an ability to change parameters, the structure and other characteristics of the system, in the course of development. The most comprehensive philosophical analysis of self-developing systems and postnonclassical rationality is presented in the works of Styopin $(2003,2011)$.

The necessity to cope with complex self-developing systems may considerably reshape the ideals and norms of science. The character of scientific study undergoes changes: more often than not, interdisciplinary, deeply focused issues come to the foreground of scientific research. To establish the boundaries of the prospective development of a system scientists have to deal with issues of an ethical character (Styopin, 2003, 2011).

It is quite obvious that a human and his/her mentality can and should be regarded as open self-developing systems because they come about as true "humanmeasured" objects: in certain cases, separation and, moreover, opposition of the object and subject of study are completely impossible.

Having reconsidered the basic principles of the cultural-historical concept introduced by Vygotsky, we arrived at the following conclusion: our ideas of mental ontogenesis and its crises as the dynamic force of development, our understanding of the systemic and semantic structure of consciousness, our assumption of the irreducibility of higher mental functions to a mere complex of elementary functions within the context of cerebral localization of higher mental functions (in its applications to clinical psychology) - this whole block of assumptions enables us to specify a range of features that may ascribe Vygotsky's cultural-historical concept rather to the postnonclassical than to the nonclassical type of scientific rationality.

What are these features? To find an answer to the question let us turn to an analysis of the works of Vygotsky and A. R. Luria.

As was previously emphasized, the most important feature of postnonclassical science is its ability to cope with complex self-developing systems.

We shall try to demonstrate that basic theses of Vygotsky's cultural-historical concept, as applied to the field of clinical psychology, contain the idea of psycho- 
logical systems, and that the these systems can be described as open self-developing systems that reveal the qualities of self-determination and self-organization.

The notion of higher mental functions is one of the fundamental ideas of $\mathrm{Vy}$ gotsky's general psychological concept. Luria gives a "definition" of higher mental functions that has already become well known: "In the view of present-day psychology, the higher mental functions of a human are presented as complex self-regulated processes, social in their origin, mediated by their structure, and conscious and arbitrary depending on the mode of functioning" (1969, p. 31).

The thesis of the social nature of mental functions in itself suggests that the human psyche represents an open system. This attribute a priori implies a high level of systemic organization of the object: only open systems possess the characteristic of self-development (Budanov, 2009; Kurdyumov, 2000).

In search of further proofs let us turn to the above-mentioned "general genetic law of cultural development," formulated by Vygotsky. This thesis has at least two consectaries vitally important for our discourse: "Every higher mental function necessarily passes through an external stage of development because that function is primarily social" (Vygotsky, 1997a, p. 105).

First, within the particular context of his description of the development of higher mental functions, Vygotsky enriched the discourse with the notion of the mediation of natural mental functions by "psychological symbols" in the process of their development. It is obvious that mediated mental functions are taken as integral complex structures and cannot be understood otherwise.

Second, the notion of interiorization is naturally derived from the general genetic law of cultural development. In his 1930 lecture "On Psychological Systems," Vygotsky described the following stages of this process: "First, an inter-psychological stage-I order, you execute. Then an extra-psychological stage-two points of the brain that are excited from the outside develop a tendency to work as a unified system and eventually form an intracortical point" (1997c, p. 106).

This rather capacious quotation not only embraces a simple description of the process of interiorization but demonstrates that an integral functional system appears as a response to an external social impact; and when the mental function becomes mediated "from the inside," there is no need for an external "stimulus." Here we can find as well the indication that a psychological system originating within the context of social interaction is essentially a psychophysiological system. In this way Vygotsky presented the general logic of the development of a psychological system, revealing its gradual complication and rationality in its transition through the different stages in the course of development. This description allows one to understand not only the meaning of "growing into the inside" but the general logic of the process of mental development as a process of the self-tuning and self-organization of the system when the accumulation of social experience leads to a change within its structural parameters. In the same work Vygotsky notes:

In the process of development and in the historical development of behavior in particular, it is not so much the functions which change (these we mistakenly studied before). Their structure and the system of their development remain the same. What is changed and modified are rather the relationships, the links between the functions... The development of such new flexible relationships between functions we will call a psychological system. (1997c, p. 92) 
In other words, he reveals the very meaning of the notion of a functional psychological system.

Thus, as early as the 1930s, long before the general theory of systems emerged, Vygotsky came close to formulating the principle of the systemic structure of higher mental functions, and he described psychological systems as open, self-tuning, and self-organizing.

In 1934, in his paper "Psychology and the Theory of Localization of Mental Functions," Vygotsky (1997d) once again turns to the principle of the systemic structure of higher mental functions and emphasizes that "no specific function is ever connected with the activity of one single brain center. It is always the product of the integral activity of strictly differentiated, hierarchically interconnected centers" (p. 140). But he goes further in the logic of his argumentation, pointing out the need to continue the study of "chronogenic localization": "Lesions with similar localization may lead to utterly different symptomatic patterns in a child and in grown-up cases" (p. 142).

Thus, in the 1930s Vygotsky approached the formulation of the principles of the dynamic organization and localization of higher mental functions. These theoretical postulates were further developed by Luria and his followers in modeling neuropsychological theory and in working out the principles of neuropsychological syndrome analysis and neuropsychological correction and rehabilitation.

We assume that the thesis of dynamic and chronogenic organization and localization of higher mental functions presents, in its most complete, crystallized form, such features of self-development of mental systems as adaptive expediency, the irreversibility of development, the opportunity to go beyond the limits of a certain level of development, the need for transition to a new qualitative level of functioning in the process of self-development, and proficiency in self-organization and self-tuning.

So, as Vygotsky puts it, higher mental functions are socially conditioned. In the process of formation they can change not only their structure but their cerebral localization as well. This thesis presents the idea that the character of the dependence of the formation of higher mental functions on biological processes undergoes changes: in the beginning their formation is determined mostly by biological mechanisms, but further on the logic of mentality to a great extent dictates the regularities of biological development. This process is a clear illustration of the mental system's self-development capability.

Another issue raised by Vygotsky that appears urgent in the context of our discourse is the search for "moving forces" of psychological development. This search brings to prominence the concept of the "crises in development" introduced by Vygotsky:

[A crisis occurs when] the forces moving the child's development at one age or another inevitably lead to rejection and disruption of the base of development of the whole age, with internal necessity determining the annulment of the social situation of development, the termination of the given period of development, and a transition to the following or higher age level. In general outline, this is the scheme of age-related dynamic development. (1998, p. 199)

Any evolution has a dialectical nature, and a crisis is believed to reveal two sides, which should be taken into consideration when we expose the psychologi- 
cal content of the crisis and its significance for further development. One side is a "destructive" feature of a crisis because the emergence of the new inevitably brings the withering of the old. But this negative side of a crisis appears as the reverse of the positive, or constructive, side.

Venturing into a present-day reconsideration of Vygotsky's ideas, we may assume that at the moment of crisis the former organization of the system (of the mental structure) is disrupted and then confronts a whole range of options for its further development. "Critical periods" are the stages that vividly display the transition from the lower level of system functioning to the higher one. The main task of a psychologist is to reveal how an adult (or a child), ill or in good health, approaches a critical stage, how the person negotiates the crisis, and which external and internal mental determinants allow the emergence of new psychological formations. A psychologist should demonstrate this tendency of the system (of a human and his/ her psyche) to transition to a higher level that will preserve all positive results of the previous stages and will present a new "zone of proximal development." As an alternative, another sequence of events may prevail: the system may follow the path of simplification and destruction and fall as a complex, self-organizing structure (one may "shrink into malady," which leads to a reduced quality of life, an impaired ability to adapt, a general aggravated state, and so on).

The introduction of the fundamentals of the cultural-historical concept in the 1930s attached special importance to designating a research method in psychology. Vygotsky formulated general methodological requirements for mental studies. These requirements, we believe, satisfy present-day demands for investigation of complex self-developing systems. Vygotsky regarded psychological syndrome analysis as epistemologically correct (Vygotsky, 1993b; 1997a, 1997c, 1997d). The methodology of syndrome analysis was further developed and theoretically and empirically supported in the neuropsychological works of Luria and his followers (Luria, 1969, 1973; and others).

When we turn to consideration of the formulation of the methodological principles of Vygotsky-Luria syndrome analysis, it is important to emphasize that in Vygotsky's works a syndrome is a structure shaped by a constellation of causallyrelated, multilevel symptoms. Primary and secondary symptoms are different in nature: in contrast to primary symptoms, secondary symptoms are purely psychological phenomena, both in their nature and in the mechanism of their derivation. Hence, secondary symptoms are affected to a greater degree by psychological matters: "The further a symptom is from the primary cause, the more responsive it is to educational and therapeutic influences" (Vygotsky, 1993b, p. 268). The complex nature of a syndrome in Vygotsky's works is supported by the implication that in the course of psychological diagnostics it is essential to distinguish not only between primary and secondary symptoms but also between the "plus and minus symptoms" (those that indicate disorders or features of adaptation and compensation). In regard to the minus symptoms, Vygotsky noted that "a defect is not only a minus, a deficit, or a weakness but also a plus, a source of strength" (1993a, p. 56) and that "along with a defect come combative psychological tendencies and the potential for overcoming the defect" (1993a, p. 57). All these ideas are of considerable importance for our discourse. 
In his work "The Diagnostics of Development and the Pedological Clinic for Difficult Children" Vygotsky (1993b) devised a requirement for the system of pedological (psychological) diagnostics that looks at the positive rather than the negative characteristics of a child-that is, at a child's compensatory potential-which could provide a basis for pedagogical correction and psychological assistance. The paper made a first attempt to describe in full the general logic of psychological syndrome analysis, providing as an example the steps in the pedological study of a sick child. Vygotsky indicated that "in practical pedological research, one must begin by absorbing a simple methodological truth: Often, a scientific researcher's primary task is to establish some fact which cannot be found directly in reality. The path of research leads from symptoms to that which lies behind them, from the constitution of symptoms to developmental diagnostics" (1993b, p. 276). He marked out the types (steps) in pedological (psychological) diagnostics: from symptomatic (the revelation of separate disorders) to syndromic (which suggests the interconnection between disorders) and further to etiological diagnostics:

The next point in our outline of pedological research is the discovery of causesnot only the determination of the data appearing as ultimate causes, but also the specification of the form of more immediate causes... The central problem in etiological analysis is discovering the mechanisms for symptom formation: how they evolve, what mechanisms help them arise and establish themselves, and what are causal conditions for particular symptoms. (1993b, p. 290)

We assume that the logic of syndrome structuring introduced by Vygotsky, his idea of distinguishing primary and secondary symptoms as well as plus and minus symptoms, his explanation of the causes of the formation and dynamic features of a syndrome-all testify to the fact that Vygotsky considered a psychological syndrome an open self-developing system endowed with the capabilities of selforganization, self-regulation, and self-determination, which allow its effective adaptation both through modifying its own structural parameters and through its interrelationship with the social environment.

Today psychological syndrome analysis is employed as a special methodological approach that provides the instrumental basis for mental studies. It is regarded as productive and adequate for the contemporary level of psychological scientific knowledge, which is characterized by the postnonclassical worldview and by recognition of the human psyche as one of the most intricate, open, "human-measured" self-developing systems.

The methodology of Vygotsky-Luria syndrome analysis has been time-tested, and its heuristic nature has been proved not only in neural psychology but also in a number of theoretical and practical studies in clinical psychology (Lebedinsky, 2003; Polyakov, 1995; Sokolova, 2012; and others). It is widely employed in psychosomatics and the psychology of corporeality (Nikolayeva, 1987; Nikolayeva \& Arina, 2003; Tkhostov, 2002). Results of our studies also demonstrate a rich variety in the methodological means of the syndrome approach in clinical psychology (Zinchenko \& Pervichko, 2012b, 2012c).

From the 1980s on, the basic principles of Vygotsky's cultural-historical concept have been objectified and have proved to be theoretically productive for a fundamentally new approach in psychosomatic studies. In the works of A. Sh. Tkhostov, P. D. Tishchenko, V. V. Nikolayeva, and their followers the idea of cor- 
poreality as a developing cultural-historical phenomenon has been formulated: "The main vector of its [corporeality's] development coincides with the central line in the development of any mental function and is believed to be transformed into a universal symbol and instrument" (Tishchenko, 2009, p. 14). Within the framework of this approach it has been demonstrated that "a developed psychosomatic phenomenon ... acquires the features of higher mental functions, such as sociality, mediation, the principal means of arbitrary control" (Nikolayeva, 2009, p. 52). The analysis of human sexuality conducted within the cultural-historical paradigm revealed the peculiarities in the socialization of this corporeal function; these peculiarities are important for assessment of the potential of a psychosomatic system for self-development. When sexuality is being shaped, "the intermental stage of its modeling is first characterized by interdiction of the function rather than its realization - that is, first comes the tendency to adopt the stereotype of inhibition but not the mode of realization" (Zinchenko, 2003, p. 66). This process may result in certain peculiarities in the development of control over sexual manifestations and typical functional disorders. They have as their basis "a dysfunction of arbitrary regulation caused by abnormality in the mediation of a natural corporeal act owing to the redundancy of semantic links" (Zinchenko \& Aizman, 2012, p. 67).

Within the context of this article, we believe it is a fact of particular importance that the specific dynamics of the modeling of normal and deviant sexuality reveal such features as adaptive rationality, the irreversibility of development, the opportunity to "step beyond" the limits of a certain level of development, the need for a transition to new levels of functioning in the process of self-development, the distinct capability for self-organization and self-tuning (which means a change of structural parameters) - all characteristic features of self-developing systems.

Psychological diagnostics conducted within the methodological tradition of syndrome analysis provide us with the material essential for the structural and genetic analysis of clinical psychological phenomena, for distinguishing certain psychological factors and the mechanisms of their functioning, and for interpreting clinical phenomenology, which pave the way for a "detailed diagnosis." Such a diagnosis assigns medical value to the data of psychological diagnostics because medicine today tends to focus on general studies of a patient's personality as well as on rehabilitation, prophylaxis, and encouragement of patients' compliance (Issel, 2008; Mezzich, 2005; Pöppel \& Wagner, 2012; Sadler, 2005; Salloum \& Mezzich, 2009; and others).

In our view, the study presented in this article testifies to the initially suggested hypothesis that the basic foundations of Vygotsky's cultural-historical concept, in its application to the field of studies of clinical psychology, reveal the principles of postnonclassical epistemology.

To give a final touch to our discourse, let us once again turn to Vygotsky's work "The Historical Meaning of the Crisis in Psychology" (1997b), to the part where he writes about the features of mentality, to wit, the capability for the selective reflection of reality: 
The mind selects the stable points of reality amidst the universal movement. It provides islands of safety in the Heraclitean stream. It is an organ of selection, a sieve filtering the world and changing it so that it becomes possible to act. In this resides its positive role-not in reflection (the non-mental reflects as well; the thermometer is more precise than sensation), but in the fact that it does not always reflect correctly, i.e., subjectively distorts reality to the advantage of the organism. (p. 290)

This assertion obviously reveals not just the idea of selectivity of perception but the notion of selective interchange between the system and the environment; it emphasizes the abilities of the system to cope with the tasks of self-adaptation, selftuning, and self-organization. Postnonclassical epistemology regards these qualities as most essential for a self-developing system. In Vygotsky's works we can find an assertion that any systemic knowledge of human mentality is impossible if we take it as an absolute: "The dialectic of psychology is at the same time the dialectic of man as the object of psychology, just as the dialectic of the natural sciences is at the same time the dialectic of nature" (Vygotsky, 1997b, p. 256).

The ideas of the anthropologization of psychological cognition are becoming more and more popular in scientific discourse (Klochko, 2007). However, their productive reflection is a matter for future studies.

Any theory is alive while it is evolving. Vygotsky's cultural-historical concept is actively employed and developed. The works of the Vygotsky-Luria academic school promote the highest standards in psychological studies and encourage the enhancement of practical psychology. Such enhancement is rather urgent for the contemporary state of the science; new trends and branches enrich its structure, and new technological instruments employed in psychological studies demand comprehension of its methodological foundations and its place among other sciences.

\section{References}

Budanov, V. G. (2009). Metodologiya sinergetiki v postneklassicheskoyj nauke i v obrazovanii [Methodology of synergetics in postnonclassical science and education]. Moscow: Book House LIBROKOM.

Guseltseva, M. S. (2009). Metodologicheskaya “optika” postneklassicheskoj i neklassicheskoj racional'nosti [Methodological "optics" of postnonclassical and nonclassical rationality]. Zhurnal prakticheskogo psihologa [Journal of practical psychology], 6, 4-44.

Issel, L. M. (2008). Health program planning and evaluation: A practical, systematic approach for community health (2nd ed.). Boston: Jones \& Bartlett.

Klochko, V. E. (2007). Zakonomernosti dvizheniya psihologicheskogo poznaniya i problema metoda nauki [Regularity in the movement of psychological cognition and the problem of the scientific method]. Metodologiya $i$ istoriya psihologii [Methodology and history of psychology], 2(1), 5-19.

Klochko, V. E. (2008). Smyslovaya teoriya myshleniya $v$ transspective stanovleniya psihologicheskogo poznaniya: Epistomologicheskij analiz [Semantic theory of thinking in the transspective formation of psychological cognition: Epistemological analysis]. Vestnik Moskovskogo Universiteta. Series 14: Psikhologiya [The Moscow University Herald. Series 14. Psychology], 2, 87-101. 
Kornilova, T. V., \& Smirnov, S. D. (2011). Metodologicheskie osnovy psihologii: Uchebnik [Methodological basics of psychology: Textbook] (2nd ed.). Moscow: Yurajt.

Kurdyumov, S. P. (2000). Samoorganizaciya slozhny sistem [The self-organization of complicated systems]. Ecologiya i zhizn' [Ecology and life], 5, 42-45.

Lebedinsky, V. V. (2003). Narusheniya psihicheskogo razvitiya $v$ detskom vozraste [The disturbance of mental development in childhood]. Moscow: Academy Publishing Center .

Lektorsky, V. A. (2006). Epistemologiya klassicheskaya i neklassicheskaya [Classical and nonclassical epistemology] (2nd ed.). Moscow: URSS.

Leont'ev, D. A. (2005). Neklassichesky vector v sovremennoj psihologii [The nonclassical vector in present-day psychology]. Postneklassicheskaya psihologiya [Postnonclassical psychology], 1, 74-94.

Luria, A. R. (1969). Vysshie korkovye funkcii i ih narushenie pri lokal'nyh porazhenijah mozga [Higher cortical functions in humans and their disruption by local brain damage] (2nd ed.). Moscow: Moscow University Press.

Luria, A. R. (1973). The working brain. An introduction to neuropsychology. London: Penguin Books.

Mezzich, J. E. (2005). Positive health: Conceptual place, dimensions and implications. Psychopathology, 38, 177-179. doi: 10.1159/000086086

Nikolayeva, V. V. (1987). Vliyanije hronicheskoj bolezni na psihiku: Psihologicheskoe issledovanie [The impact of chronic illness on the psyche: Psychological research]. Moscow: Moscow University Press.

Nikolayeva, V. V. (2009). Klinicheskaya psihologiya telesnosti [Clinical psychology of corporality]. In V. V. Nikolayeva (Ed.), Psihosomatika: Telesnost' i kul'tura: Uchebnoe posobije dlya vuzov [Psychosomatics: Corporality and culture: Tutorial for universities] (pp. 49-72). Moscow: Academic Project.

Nikolayeva, V. V., \& Arina, A. G. (2003). Kliniko-psihologicheskie problemy psihologii telesnosti [Clinical and psychological problems in corporeality psychology]. Psihologicheskij Zhurnal [Journal of psychology], 24(1), 119-126.

Polyakov, Yu. F. (1995). Teoretiko-metodologicheskije problemy patopsihologii. Vvedenije [Theoretical and methodological issues in abnormal psychology. Introduction]. In E. T. Sokolova \& V. V. Nikolayeva (Eds.), Osobennosti lichnosti pri pogranichnyh rasstrojstvah i somaticheskih zabolevaniyah [Personality features in borderline disorders and somatic diseases] (pp. 9-26). Moscow: SvR-Argus.

Pöppel, E., \& Wagner, B. (2012). Von Natur aus kreativ [By nature creative]. Munich: Hanser. doi: $10.3139 / 9783446432864$

Prigogine, I. (1989). The philosophy of instability. Futures, 21(4), 396-400. doi: 10.1016/S00163287(89)80009-6

Sadler, J. (Ed.). (2005). Values and psychiatric diagnosis. Oxford, U.K.: Oxford University Press.

Salloum, I. M., \& Mezzich, J. E. (Eds.). (2009). Psychiatric diagnosis: Challenges and prospects. Oxford, U.K.: Wiley-Blackwell. doi: 10.1002/9780470743485

Sokolova, E. E. (2011). Est' li budusheje u teorii deyatel'nosti? [Is there a future for the theory of activity?]. Vestnik Moskovskogo Universiteta. Series 14: Psikhologiya [The Moscow University Herald. Series 14. Psychology], 4, 129-140.

Sokolova, E. T. (2012). Kul'turno-istoricheskaya i kliniko-psihologicheskaya perspektiva issledovaniya fenomenov subjektivnoj neopredeljonnosti [Cultural-historical and clinical-psychological perspective on research on the phenomena of subjective uncertainty]. Vestnik Moskovskogo Universiteta. Series 14: Psikhologiya [The Moscow University Herald. Series 14. Psychology], 2, 37-48. 
Styopin, V. S. (2003). Samorazvivajuwiesja sistemy i postneklassicheskaja racional'nost' [Selfdeveloping systems and postnonclassical rationality]. Voprosy Filosofii [Issues in philosophy], 8, 5-17.

Styopin, V. S. (2011). Istorija i filosofija nauki [The history and philosophy of science]. Moscow: Academic Project.

Tishchenko, P. D. (2009). Psihosomaticheskaya problema (objektivnyj metod i kul'turologicheskaya interpretaciya) [The psychosomatic problem (objective method and cultural interpretation)]. In V. V. Nikolayeva (Ed.), Psihosomatika: Telesnost' i kul'tura: Uchebnoe posobije dlya vuzov [Psychosomatics: Corporality and culture: Tutorial for universities] (pp. 11-22). Moscow: Academic Project.

Tkhostov, A. Sh. (2002). Psihologija telesnosti [The psychology of corporality]. Moscow: Smysl.

Vygotsky, L. S. (1993a). Defect and compensation. In R. W. Rieber \& A. S. Carton (Eds.), The collected works of L. S. Vygotsky: The fundamentals of defectology (abnormal psychology and learning disabilities), 2, 52-64. New York: Plenum Press. doi: 10.1007/978-1-4615-2806-7

Vygotsky, L. S. (1993b). The diagnostics of development and the pedological clinic for difficult children. In R. W. Rieber \& A. S. Carton (Eds.), The collected works of L. S. Vygotsky: The fundamentals of defectology (abnormal psychology and learning disabilities), 2, 241-291. New York: Plenum Press. doi: 10.1007/978-1-4615-2806-7

Vygotsky, L. S. (1997a). Genesis of higher mental functions. In R. W. Rieber \& A. S. Carton (Eds.), The collected works of L. S. Vygotsky: The history of the development of the higher mental functions, 4, 97-120. New York: Plenum Press. doi: 10.1007/978-1-4615-5939-9

Vygotsky, L. S. (1997b). The historical meaning of the crisis in psychology: A methodological investigation. In R. W. Rieber \& A. S. Carton (Eds.), The collected works of L. S. Vygotsky: Problems of the Theory and History of Psychology, 3, 233-370. New York: Plenum Press. doi: 10.1007/978-1-4615-5939-9

Vygotsky, L. S. (1997c). On psychological systems. In . W. Rieber \& A. S. Carton (Eds.), The collected works of L. S. Vygotsky: Problems of the theory and history of psychology, 3, 91-108. New York: Plenum Press. doi: 10.1007/978-1-4615-5893-4

Vygotsky, L. S. (1997d). Psychology and the theory of localization of mental functions. In . W. Rieber \& A. S. Carton (Eds.), The collected works of L. S. Vygotsky: Problems of the theory and history of psychology, 3, 139-146. New York: Plenum Press. doi: 10.1007/978-1-46155893-4

Vygotsky, L. S. (1998). The problem of age. In R. W. Rieber (Ed.), The collected works of L. S. Vygotsky: Child psychology, 5, 187-205. New York: Plenum Press. doi: 10.1007/978-1-46155401-1

Zinchenko, V. P. (2006). Zhyvyje metafory smysla [Lively metaphors of sense]. Voprosy psihologii [Issues in psychology], 5, 100-113.

Zinchenko, V. P., \& Smirnov, S. D. (1983). Metodologicheskie voprosy psihologii [Methodological questions in psychology]. Moscow: Moscow University Press.

Zinchenko, Yu. P. (2003). Klinicheskaja psihologija seksual'nosti cheloveka v kontekste kul'turnoistoricheskogo podhoda [The clinical psychology of human sexuality in the context of a cultural-historical approach]. Moscow: Prospekt.

Zinchenko, Yu. P. (2011). Metodologicheskie problemy fundamental'nyh i prikladnyh psihologicheskih issledovanij [Methodological problems in basic and applied psychological research]. Nacional'nyj Psihologicheskij Zhurnal [National psychological journal], 1(5), $42-49$. 
Zinchenko, Yu. P., \& Aizman, N. I. (2012). Osobennosti seksual'noj sfery studentok vuza [Features of the sexual sphere of female students]. Sibirskij psihologicheskij zhurnal [Siberian psychological journal], 43, 59-67.

Zinchenko, Yu. P., \& Pervichko, E. I. (2012a). The methodology of syndrome analysis within the paradigm of "qualitative research" in clinical psychology. Psychology in Russia: State of the Art, 5, 157-184. doi: 10.11621/pir.2012.0010

Zinchenko, Yu. P., \& Pervichko, E. I. (2012b). Postneklassicheskaja metodologija v klinicheskoj psihologii: Nauchnaja shkola L. S. Vygotskogo-A. R. Lurija [Postnonclassical methodology in clinical psychology: Vygotsky-Luria school]. Nacional'nyj Psihologicheskij Zhurnal [National psychological journal], 2(8), 42-49.

Zinchenko, Yu. P., \& Pervichko, E. I. (2012c). Sindromnyj podhod v psihologii telesnosti (na primere issledovaniya bol'nyh s prolapsom mitral'nogo klapana) [Syndrome approach to the psychology of corporality (patients with a prolapsed mitral valve, for example)]. Vestnik Moskovskogo Universiteta. Series 14: Psikhologiya [The Moscow University Herald. Series 14. Psychology], 2, 57-67. 